\title{
Catch-up growth and nutritional status of preterms born at a Ugandan tertiary hospital: An Observational study.
}

Flaviah Namiiro ( $\sim$ bnflaviah@gmail.com )

Mulago Hospital

Anthony Batte

Makerere University

Joseph Rujumba

Makerere University

Nicolette Nabukeera

Makerere University

lan Munabi

Makerere University

Violet Kayom

Makerere University

Robert Serunjogi

Makerere University

Sarah Kiguli

Makerere University

\section{Research Article}

Keywords: Catch up growth, Prematurity, Low birth weight, Stunting, Wasting, Underweight

Posted Date: December 18th, 2020

DOI: https://doi.org/10.21203/rs.3.rs-126512/v1

License: (c) (1) This work is licensed under a Creative Commons Attribution 4.0 International License.

Read Full License 


\section{Abstract}

Introduction Advances in neonatal care have led to the increasing survival of preterm/low birth weight infants worldwide. However, there is limited data on growth outcomes following preterm births especially in low and middle income countries. We assessed the catch-up growth, nutritional status and associated factors of Ugandan children who were born preterm/ low birth weight at Mulago National Referral Hospital.

Methods: We enrolled children aged 22-38 months who had been born as preterm with low birth weight and their mothers. Participants were identified and recruited from the follow up clinic for preterm babies discharged from the neonatal unit of Mulago Hospital. Anthropometric measurements for mothers and children were taken. The children's weight for height z-scores, height for age z-scores, weight for age zscores, head circumference and mid upper arm circumference (MUAC) were taken and the mothers' body mass index were generated based on the World Health Organization standards.

Results: Of the 251 children and mother pairs recruited, 129 children $(51.4 \%)$ were male, the mean age was 29.7 months ( $S D \pm 4.5$ ) and the mean maternal age was $29.9(\mathrm{SD} \pm 5.3) .101(40.1 \%)$ of the children enrolled had attained catch up growth on the normal anthropometric measurements for their age. Among the participants, the prevalence of wasting, underweight and stunting was: 8 (3.2\%), $36(14.4 \%)$ and 106 $(42.2 \%)$ respectively. Factors associated with stunting were male sex (AOR 2.36, 95\% Cl 1.42 to 3.95); p=0.001), maternal age $\leq 25$ years: AOR $2.27(95 \% \mathrm{Cl} 1.13,4.52) ; \mathrm{p}=\mathbf{0 . 0 2 0}$, and maternal height $<150 \mathrm{~cm}$ : AOR 5.57(95\% Cl 1.90, 16.94); $P=0.002$. Associations with underweight in the children were; birth weight $\leq 1500$ gms: AOR 2.38(95\% Cl 1.14, 4.95); $p=0.020$ and post-natal hospitalization of more than 14 days: AOR 5.93(95\% Cl 1.96, 17.90); $p=0.002$. For $246(98.8 \%)$ participants, MUAC was normal $(\geq 12.5 \mathrm{~cm})$ and for $216(86.8 \%)$ the head circumference was within normal range for age.

Conclusion: Of the children born preterm/LBW $40.1 \%$ of the participants had attained the expected catch up growth at 2 to 3 years of age, $42.2 \%$ were observed to be stunted while $14.4 \%$ were underweight both higher than the national levels. Targeted interventions are specifically needed for children born with very low birth weight, those requiring long postnatal hospitalization, males and those born to short or young mothers.

\section{Background}

Prematurity is on the rise globally, contributing about 15 million births annually [1]. More than $60 \%$ of preterm with low birth weight (LBW) babies are born in Asia and Sub Saharan Africa [2]. Prematurity causes an estimated one million neonatal deaths worldwide and it is a significant contributor to morbidities among survivors extending to adulthood [3, 4].

Uganda is ranked 13th of the 184 countries in the world with the highest number of babies born prematurely; with approximately $14 \%$ of babies born preterm $[1,5]$. Although mortality has been high among preterm/LBW infants, advances in neonatal care have led to better survival of preterm and low 
birth weight infants worldwide [2,6]. Therefore, children born preterm should be followed up with long term growth monitoring with the aim of achieving catch-up growth as early as possible to combat health consequences like undernutrition later in life [7, 8]. Growth status is defined by normal anthropometric measurements for age and sex with weight and height $z$ scores $>-2$ SDs of the reference population [9, 10]. At two years of age, children born preterm are expected to have caught up on the normal growth curve with their appropriate to gestation age (AGA) counterparts [11-13]. However, some studies have reported that at this age some children are still stunted and underweight, and this growth restriction persists into adulthood [14-17]. Survivors are at risk of long-term consequences and require follow up beyond the neonatal period $[18,19]$. It is therefore important that early childhood follow up identifies children poorly progressing in growth to ensure that appropriate interventions are instituted at the earliest opportunity $[15,20,21]$.

Compared to high income countries, in low and middle income countries (LMICs) there is limited literature on post- hospital discharge growth status of preterm children $[7,8]$. We therefore sought to evaluate the catch up growth, nutritional status and associated factors for children aged at 22-38 months born preterm/low birth weight in a low resource setting.

\section{Methods}

This was a cross sectional survey which assessed the anthropometric measurements of children aged 22-38 months born preterm/low birth weight (LBW). The study was conducted at the preterm/LBW follow up clinic of Mulago National Referral Hospital, Kampala, Uganda. This clinic attends to any baby born with weight $\leq 2500 \mathrm{gms}$ and majority of these are usually pre-term babies. This is a follow up clinic for babies discharged from Mulago hospital neonatal unit. A total of 251 child and caretaker pairs of eligible children were recruited from November 2019 to February 2020. Eligible children were children aged 22-38 months, and weighed $\leq 2000$ grams at birth and attended the preterm/LBW follow up clinic at Mulago Hospital. For inclusion in the study, hospital outpatient records were evaluated for children who were aged 22-38months at the time of enrolment (were attending and registered in the follow up clinic between January 2017 to February 2018 and had a birth weight of $\leq 2000$ grams). A list of the eligible children was made and every second mother was given a telephone call by the research team and was requested to bring back the child to the clinic for participation in the study. However, using this systematic sampling of every second child, we were only able to reach 108 out of the 506 eligible participants. We therefore consecutively called up every caretaker. A large proportion of telephone calls to the caretakers were not picked after three attempts. There were also some incomplete or wrong telephone numbers and some numbers were not validated or were out of service. A few caretakers/mothers were not able to come back to the clinic despite responding to our call.

\section{Study Measurements}

Mother/caretaker-infant pairs came to the clinic on the appointed days. Research assistants who were nurses obtained both infant and maternal demographics (age, sex, birth weight and socioeconomic 
characteristics). Other data collected included: mode and type of delivery, estimated distance from hospital, duration in hospital, duration of exclusive breastfeeding and duration in the follow up clinic. Anthropometric measurements were taken for each child including: weight, height/length, head circumference and mid-upper arm circumference. Mother's weight, height and body mass index (BMI) were also measured. The weights were taken using a digital portable SECA® weighing scale. Weight was taken while child was wearing light clothing and bare feet. The values were recorded to one decimal point. Height was measured to the nearest $0.1 \mathrm{~cm}$ precision using a stadiometer. All measurements were taken once by a trained research assistant.

\section{Analysis And Data Management}

The WHO Anthropometrics software was used to convert height, weight and age measurements to heightfor-age z-scores (HAZ), weight-height z-scores (WHZ) and weight-for-age z-scores (WAZ) which were used to classify stunting, wasting and underweight respectively. Child was considered to have caught up or attained normal growth if their z-scores were above - 2SD of the reference population and to have undernutrition when their z-scores below - 2SD. To establish the association of infant and maternal factors with nutritional status for wasting, underweight and stunting, stepwise logistic regression analysis was performed. Factors that were found significant at bivariate analysis were further fitted in model 1 and 2 at multivariate analysis. We used multivariable logistic regression analysis to estimate adjusted odds ratios (AORs) along with their $95 \%$ confidence intervals (Cls) for the associations between each infant and maternal characteristic with child anthropometric outcomes (below - 2 SD) as the reference category. For all statistical tests a $p<0.05$ was considered statistically significant.

Data were analyzed using STATA version 15 statistical software (StataCorp. 2017 College Station, TX: StataCorp LLC). The severity of stunting, underweight and wasting by prevalence ranges among children were assessed using the WHO classification for assessing severity of malnutrition by prevalence ranges among children under-5 years of age[10].

\section{Results}

\section{Baseline characteristics of the children}

Of the 923 children registered in the follow up clinic from January 2017 to February 2018; 506 met our inclusion criteria (Fig. 1). We enrolled 251 children and the mean age was 29.7 months (SD \pm 4.5 ) and $51.4 \%$ were male. Children with birth weight $\leq 1500$ gm were $104(41.6 \%)$ and those $>1500$ were 146 (58.4\%). The median duration of hospital stay post- delivery was 12 days (IQR: 7-18).

The summary of the baseline characteristics for the study participants are summarized in Table 1 below. The ratio of male to female was 0.9:1. Most of the participants were delivered by spontaneous vertex delivery 177 (70.5\%) and majority were singletons 179 (71.3\%). 
Table 1

Baseline characteristics for the participants

\begin{tabular}{|lll|}
\hline Variable & Frequency & Percentage $\%$ \\
\hline Sex of the child & & \\
\hline Male & 129 & 51.4 \\
\hline Female & 122 & 48.6 \\
\hline Age of the child & & \\
\hline $22-30$ months & 141 & 56.2 \\
\hline $31-38$ months & 110 & 43.8 \\
\hline Mode of delivery & & \\
\hline Caesarean section & 74 & 29.5 \\
\hline Vaginal delivery & 177 & 70.5 \\
\hline Type of delivery & & \\
\hline Multiple & 72 & 28.7 \\
\hline Singleton & 179 & 71.3 \\
\hline Birth weight & & \\
\hline$\leq 1500$ gm & 134 & 53.4 \\
\hline$>1500$ gm & 104 & 41.6 \\
\hline Child EBF & 146 & 58.4 \\
\hline Yes & & \\
\hline No & & \\
\hline Duration of hospital stay & & 39.0 \\
\hline $1-7$ days & & \\
\hline $8-14$ days & & \\
\hline $15-28$ days & & \\
\hline
\end{tabular}

EBF: Exclusive Breastfeeding for first 6 months of life Maternal/caretaker Characteristics

Among the maternal characteristics summarized in Table 2, the anthropometric measurements for 236 mothers were included for analysis because 15 participants were accompanied by other caretakers (10 
fathers, 2 grandparents and one aunt). 
Table 2

Baseline characteristics for the mothers

\begin{tabular}{|c|c|c|}
\hline Variable & Frequency & Percentage $\%$ \\
\hline \multicolumn{3}{|l|}{ Age } \\
\hline$\leq 25$ years & 50 & 19.9 \\
\hline $26-30$ years & 103 & 41.1 \\
\hline$>30$ years & 98 & 39.04 \\
\hline \multicolumn{3}{|c|}{ Estimated Distance from home to hospital } \\
\hline$<5 \mathrm{Km}$ & 28 & 11.1 \\
\hline $5-15 \mathrm{~km}$ & 212 & 84.5 \\
\hline$\geq 15 \mathrm{Km}$ & 11 & 4.4 \\
\hline \multicolumn{3}{|l|}{ Education level } \\
\hline Primary below/none & 51 & 20.3 \\
\hline Secondary/tertiary level & 200 & 79.7 \\
\hline \multicolumn{3}{|l|}{ Marital status } \\
\hline Married / co-habiting & 199 & 79.3 \\
\hline Single / divorced/ separated & 52 & 20.7 \\
\hline \multicolumn{3}{|l|}{ Employment status } \\
\hline Employed & 164 & 65.3 \\
\hline Not employed & 87 & 34.7 \\
\hline \multicolumn{3}{|l|}{ Have social support } \\
\hline Yes & 224 & 89.6 \\
\hline No & 26 & 10.4 \\
\hline \multicolumn{3}{|l|}{ Number of children } \\
\hline 1-2 children & 111 & 44.9 \\
\hline 3-4 children & 87 & 35.2 \\
\hline$>5$ children & 49 & 19.9 \\
\hline \multicolumn{3}{|l|}{ Mother's BMI } \\
\hline < 18.5 (Underweight) & 1 & 0.4 \\
\hline $18.5-\leq 25$ (Normal Range) & 106 & 42.2 \\
\hline
\end{tabular}




\begin{tabular}{|lll|}
\hline Variable & Frequency & Percentage \% \\
\hline $25.0-<30$ (Overweight) & 78 & 31.1 \\
\hline$\geq 30$ (Obese) & 66 & 26.3 \\
\hline
\end{tabular}

\section{BMI Body Mass Index Growth And Nutrition Status Of The Children}

The summary of growth status for the participants using anthropometric measurements by sex and age are shown in Fig. 2 and Table 3. Of the participants, 101 (40.2\%) had caught up on the normal anthropometric measurements $z$ scores $>-2$ SD of the reference population for their age and sex.

The prevalence for wasting (weight for height z-score <-2SD) was 8 (3.2\%), underweight (weight for age zscore <-2 SD) 36 (14.4\%) and the prevalence of stunting (height for age $z$-score <-2) was 106 (42.2\%). There were more boys stunted, 64 out of 106 participants compared to girls $(\mathbf{p}=\mathbf{0 . 0 0 1})$. There was no statistically significant difference based on sex for the children who were wasted or underweight. For 246 (98.8\%) participants, MUAC was normal $(\geq 12.5 \mathrm{~cm}$ ) and for $216(86.8 \%)$ the head circumference was within normal range for age.

The scatter plot graphs show individual growth parameters (weight and height/length) for the children and their corresponding age and sex based on the 2006 WHO multicenter reference growth population: A - Weight for Height/Length, B - Weight for Age, C - Height/Length for Age.

The z-scores for the weight for age, weight for height, height for age, and head circumference for the participants are summarized in Table 3. 
Table 3

Summary of Participants' anthropometric measurements

\begin{tabular}{|c|c|c|c|c|c|c|c|}
\hline & & $<-3 S D$ & $\begin{array}{l}>=-3 S D \\
\text { to }<-2 S D\end{array}$ & $\begin{array}{l}>=-2 S D \text { to }< \\
2 S D\end{array}$ & $\begin{array}{l}>=2 S D \text { to }< \\
3 S D\end{array}$ & $>=3 S D$ & Total \\
\hline \multirow{4}{*}{$\begin{array}{l}\text { Weight } \\
\text { For Age }\end{array}$} & \multirow{3}{*}{$\begin{array}{l}\text { Male } \\
\mathrm{n} \% \\
\text { Female } \\
\mathrm{n} \%\end{array}$} & $0(0.0)$ & $18(14.8)$ & 104 (85.3) & - & - & 122 \\
\hline & & $1(0.8)$ & $12(9.3)$ & $116(89.9)$ & - & - & 129 \\
\hline & & $1(0.4)$ & $30(12)$ & $220(87.7)$ & - & - & 251 \\
\hline & \multicolumn{7}{|l|}{ Total } \\
\hline \multirow{4}{*}{$\begin{array}{l}\text { Weight } \\
\text { For } \\
\text { Height }\end{array}$} & \multirow{3}{*}{$\begin{array}{l}\text { Male } \\
\text { n\% } \\
\text { Female } \\
\text { n\% }\end{array}$} & $2(1.7)$ & $2(1.7)$ & 112 (92.6) & $4(3.3)$ & $1(0.8)$ & 121 \\
\hline & & $1(0.8)$ & $3(2.3)$ & $124(96.1)$ & $1(0.8)$ & $0(0.0)$ & 129 \\
\hline & & $3(1.2)$ & $5(2.0)$ & $236(94.4)$ & $5(2.0)$ & $1(0.4)$ & 250 \\
\hline & \multicolumn{7}{|l|}{ Total } \\
\hline \multirow{4}{*}{$\begin{array}{l}\text { Height } \\
\text { For Age }\end{array}$} & \multirow{4}{*}{$\begin{array}{l}\text { Male } \\
\mathrm{n} \% \\
\text { Female } \\
\mathrm{n} \% \\
\text { Total }\end{array}$} & 26() 21.3 & 39 (32.0) & $56(45.9)$ & $1(0.8)$ & - & 122 \\
\hline & & 15 & $26(20.2)$ & 88 (68.2) & $0(0.0)$ & - & 129 \\
\hline & & & $65(25.9)$ & $144(57.4)$ & $1(0.4)$ & & 251 \\
\hline & & ) & & & & & \\
\hline \multirow{4}{*}{$\begin{array}{l}\text { Head } \\
\text { Circumference }\end{array}$} & \multirow{2}{*}{$\begin{array}{l}\text { Male } \\
\mathrm{n} \%\end{array}$} & \multirow{2}{*}{$\begin{array}{l}2(1.7) 1 \\
(0.8)\end{array}$} & $2(1.7)$ & 112 (92.6) & $4(3.3)$ & $1(0.8)$ & 121 \\
\hline & & & $3(2.3)$ & $124(96.1)$ & $1(0.8)$ & $0(0.0)$ & 129 \\
\hline & $\mathrm{n} \%$ & $3(1.2)$ & $5(2.0)$ & $236(94.4)$ & $5(2.0)$ & $1(0.4)$ & 250 \\
\hline & Total & & & & & & \\
\hline
\end{tabular}

Factors Associated With Nutritional Status Of The Children

After bivariate and multivariate analysis to establish the association between child and maternal characteristics with the nutrition status are summarized in Tables $4 \& 5$ for underweight and stunting respectively.

Birth weight $\leq 1500 \mathrm{gm}$ and hospital stay of more than 14 days were found to have an association with underweight (AOR 2.36 95\% Cl 1.13,4.95, p= 0.043) and (AOR 5.77, 95\% Cl1.88,17.67, $\mathrm{p}=0.002$ ) respectively as shown in Table 4. 
Table 4

Bivariate and multivariate analysis of Child factors associated with underweight

\begin{tabular}{|c|c|c|c|c|c|c|}
\hline \multirow[t]{3}{*}{ Variables } & \multicolumn{2}{|c|}{ Growth status the preterm children } & \multirow{3}{*}{$\begin{array}{l}\text { COR 95\% } \\
\mathrm{Cl}\end{array}$} & \multirow{3}{*}{$\begin{array}{l}P \\
\text { value }\end{array}$} & \multirow{3}{*}{$\begin{array}{l}\text { AOR 95\% } \\
\mathrm{Cl} \text { * }\end{array}$} & \multirow{3}{*}{$\begin{array}{l}\mathrm{P} \\
\text { value }\end{array}$} \\
\hline & $\begin{array}{l}\text { Underweight } \\
\text { (W/A Z-score } \\
<-2)\end{array}$ & $\begin{array}{l}\text { Not Underweight W/A } \\
\text { Z-score } \geq-2)(n=216) \\
(f, \%)\end{array}$ & & & & \\
\hline & $(n=35)(f, \%)$ & & & & & \\
\hline \multicolumn{7}{|l|}{$\begin{array}{l}\text { Sex of the } \\
\text { child }\end{array}$} \\
\hline Male & 17(48.6) & $112(51.9)$ & $\begin{array}{l}0.87 \\
(0.43 \\
1.79)\end{array}$ & 0.719 & & \\
\hline Female & $18(51.4)$ & 104(48.2) & & & & \\
\hline \multicolumn{7}{|l|}{$\begin{array}{l}\text { Age of the } \\
\text { child }\end{array}$} \\
\hline $\begin{array}{l}22-30 \\
\text { months }\end{array}$ & 17(48.6) & $124(57.4)$ & 1 & & & \\
\hline $\begin{array}{l}31-38 \\
\text { months }\end{array}$ & $18(51.4)$ & $92(42.6)$ & $\begin{array}{l}1.42 \\
(0.70 \\
2.92)\end{array}$ & 0.330 & & \\
\hline \multicolumn{7}{|l|}{$\begin{array}{l}\text { Mode of } \\
\text { delivery } b\end{array}$} \\
\hline $\begin{array}{l}\text { Caesarean } \\
\text { section }\end{array}$ & $10(28.6)$ & 64(29.6) & $\begin{array}{l}0.95 \\
(0.43 \\
2.09)\end{array}$ & 0.899 & $\begin{array}{l}0.81(0.36, \\
1.89)\end{array}$ & 0.639 \\
\hline $\begin{array}{l}\text { Vaginal } \\
\text { delivery }\end{array}$ & $25(71.4)$ & 152(70.4) & & & & \\
\hline \multicolumn{7}{|l|}{$\begin{array}{l}\text { Type of } \\
\text { delivery a }\end{array}$} \\
\hline Multiple & $8(22.9)$ & $64(29.6)$ & $\begin{array}{l}0.70 \\
(0.30 \\
1.63)\end{array}$ & 0.413 & $\begin{array}{l}0.71(0.29 \\
1.72)\end{array}$ & 0.450 \\
\hline Singleton & $27(77.1)$ & 152(70.4) & & & & \\
\hline $\begin{array}{l}\text { Birth weight } \\
\text { b }\end{array}$ & & & & & & \\
\hline
\end{tabular}

Reference group: Not Underweight. EBF: Exclusive Breastfeeding, COR: Crude Odds Ratio, Cl: Confidence interval. ${ }^{a}$ Adjusted for Number of children, Previous preterm deliveries. ${ }^{b}$ Adjusted for Number of children, Previous preterm deliveries, Multiple births 


\begin{tabular}{|c|c|c|c|c|c|c|}
\hline \multirow[t]{3}{*}{ Variables } & \multicolumn{2}{|c|}{ Growth status the preterm children } & \multirow{3}{*}{$\begin{array}{l}\text { COR 95\% } \\
\mathrm{Cl}\end{array}$} & \multirow{3}{*}{$\begin{array}{l}P \\
\text { value }\end{array}$} & \multirow{3}{*}{$\begin{array}{l}\text { AOR 95\% } \\
\text { Cl * }\end{array}$} & \multirow{3}{*}{$\begin{array}{l}\mathrm{P} \\
\text { value }\end{array}$} \\
\hline & $\begin{array}{l}\text { Underweight } \\
\text { (W/A Z-score } \\
<-2)\end{array}$ & $\begin{array}{l}\text { Not Underweight W/A } \\
\text { Z-score } \geq-2)(n=216) \\
(f, \%)\end{array}$ & & & & \\
\hline & $(n=35)(f, \%)$ & & & & & \\
\hline $\begin{array}{l}\leq 1500 \\
\text { grams }\end{array}$ & $21(60.0)$ & $83(38.6)$ & $\begin{array}{l}2.38 \\
(1.14 \\
4.95)\end{array}$ & 0.020 & $\begin{array}{l}2.36 \\
(1.13 \\
4.95)\end{array}$ & 0.023 \\
\hline$>1500$ grams & $14(40.0)$ & 132(61.4) & & & & \\
\hline \multicolumn{7}{|l|}{ Child EBF b } \\
\hline Yes & $11(31.4)$ & 75(34.7) & 1 & 1 & & \\
\hline No & $24(68.6)$ & $141(65.3)$ & $\begin{array}{l}0.86(0.4 \\
1.85)\end{array}$ & 0.703 & $\begin{array}{l}0.83(0.35 \\
1.95)\end{array}$ & 0.669 \\
\hline \multicolumn{7}{|l|}{$\begin{array}{l}\text { Duration of } \\
\text { hospital stay } \\
\text { b }\end{array}$} \\
\hline $1-7$ days & $12(34.3)$ & $122(56.5)$ & 1 & 1 & 1 & \\
\hline $8-14$ days & $16(45.7)$ & $82(38)$ & $\begin{array}{l}1.98 \\
(0.89 \\
4.41)\end{array}$ & 0.093 & $\begin{array}{l}\text { 1.84(0.81, } \\
4.15)\end{array}$ & 0.140 \\
\hline $15-28$ days & $7(20)$ & $12(5.6)$ & $\begin{array}{l}5.93 \\
(1.96 \\
17.90)\end{array}$ & 0.002 & $\begin{array}{l}5.77(1.88, \\
17.67)\end{array}$ & 0.002 \\
\hline \multicolumn{7}{|l|}{$\begin{array}{l}\text { Completed } \\
\text { one year in } \\
\text { care }^{\text {b }}\end{array}$} \\
\hline Yes & $19(54.3)$ & $119(55.1)$ & $\begin{array}{l}1.03(0.50 \\
2.12)\end{array}$ & 0.929 & $\begin{array}{l}0.95 \\
(0.45 \\
0.36)\end{array}$ & 0.886 \\
\hline No & $16(45.7)$ & $97(44.9)$ & 1 & 1 & & \\
\hline
\end{tabular}

The factors associated with stunting were male sex (AOR 2.33, 95\% $\mathrm{Cl} 1.42$ to $4.04, \mathrm{p}=0.001$ ), maternal age less than $\leq 25$ years when compared to $26-30$ years (AOR 2.16, 95\% Cl1.02, 4.54, $p=0.043$ ) and maternal height less than $150 \mathrm{~cm}$ (AOR 4.87, 95\% Cl1.70, 13.93, $\mathrm{p}=0.003$ ), Table 5. 
Table 5

Association between Child and Maternal characteristics with Stunting

\begin{tabular}{|c|c|c|c|c|c|c|}
\hline \multirow[t]{3}{*}{ Variables } & \multicolumn{2}{|c|}{$\begin{array}{l}\text { Growth status the preterm } \\
\text { children }\end{array}$} & \multirow[t]{3}{*}{ COR 95\% Cl } & \multirow[t]{3}{*}{$\begin{array}{l}P \\
\text { value }\end{array}$} & \multirow[t]{3}{*}{ AOR 95\% Cl } & \multirow[t]{3}{*}{$\begin{array}{l}\mathrm{P} \\
\text { value }\end{array}$} \\
\hline & $\begin{array}{l}\text { Stunted } \\
\text { (H/A Z- } \\
\text { score <-2) }\end{array}$ & $\begin{array}{l}\text { Not Stunted } \\
\text { H/A Z-score } \\
\geq-2 \text { ) }\end{array}$ & & & & \\
\hline & $\begin{array}{l}(n=35)(f, \\
\%)\end{array}$ & $\begin{array}{l}(n=216)(f, \\
\%)\end{array}$ & & & & \\
\hline \multicolumn{7}{|l|}{$\begin{array}{l}\text { Sex of the } \\
\text { child }\end{array}$} \\
\hline Male & $64(61)$ & 58(39.7) & $2.36(1.42,3.95)$ & 0.001 & $2.39(1.42,4.04)$ & 0.001 \\
\hline Female & $41(39)$ & $88(60.3)$ & 1 & & & \\
\hline \multicolumn{7}{|l|}{ Age } \\
\hline$\leq 25$ years & $30(28.6)$ & 20(13.7) & $2.27(1.13,4.52)$ & 0.020 & $2.16(1.02,4.54)$ & 0.043 \\
\hline $26-30$ years & $41(39)$ & $62(42.5)$ & 1 & & & \\
\hline > 30 years & $34(32.4)$ & 64(43.8) & $0.80(0.45,1.43)$ & 0.454 & & \\
\hline \multicolumn{7}{|l|}{$\begin{array}{l}\text { Marital } \\
\text { status }\end{array}$} \\
\hline $\begin{array}{l}\text { Married / co- } \\
\text { habiting }\end{array}$ & 77(73.3) & $122(83.6)$ & 1 & & & \\
\hline $\begin{array}{l}\text { Single / } \\
\text { divorced/ } \\
\text { separated }\end{array}$ & $28(26.7)$ & $24(16.4)$ & $1.84(1.00,3.42)$ & 0.050 & $1.79(0.93,3.45)$ & 0.079 \\
\hline \multicolumn{7}{|l|}{$\begin{array}{l}\text { BMI for } \\
\text { caretaker }\end{array}$} \\
\hline$<18.5$ & $0(0)$ & $1(0.7)$ & - & - & & \\
\hline 18.5 to $<25$ & $50(50)$ & $50(37)$ & 1 & & & \\
\hline 25 to $<30$ & $30(30)$ & 43(31.9) & $0.70(0.38,1.28)$ & 0.247 & $0.72(0.38,1.34)$ & 0.300 \\
\hline$\geq 30$ & $20(20)$ & 41(30.4) & $0.49(0.25,0.94)$ & 0.034 & $0.64(0.34,1.29)$ & 0.210 \\
\hline \multicolumn{7}{|l|}{$\begin{array}{l}\text { Maternal } \\
\text { Height* }\end{array}$} \\
\hline $\begin{array}{l}\text { Less than } \\
150\end{array}$ & $18(18.0)$ & $4(4.4)$ & $5.00(1.79,13.99)$ & 0.002 & $4.87(1.7,13.93)$ & 0.003 \\
\hline $150-154.9$ & $22(22.0)$ & 28(20.7) & $1.31(0.64,2.69)$ & 0.462 & $1.2(0.58,2.51)$ & 0.622 \\
\hline $155-159.9$ & $30(30.0)$ & $50(37.0)$ & 1 & & 1 & \\
\hline
\end{tabular}




\begin{tabular}{|c|c|c|c|c|c|c|}
\hline \multirow[t]{3}{*}{ Variables } & \multicolumn{2}{|c|}{$\begin{array}{l}\text { Growth status the preterm } \\
\text { children }\end{array}$} & \multirow[t]{3}{*}{ COR 95\% Cl } & \multirow[t]{3}{*}{$\begin{array}{l}P \\
\text { value }\end{array}$} & \multirow[t]{3}{*}{ AOR $95 \% \mathrm{Cl}$} & \multirow[t]{3}{*}{$\begin{array}{l}\mathrm{P} \\
\text { value }\end{array}$} \\
\hline & $\begin{array}{l}\text { Stunted } \\
\text { (H/A Z- } \\
\text { score <-2) }\end{array}$ & $\begin{array}{l}\text { Not Stunted } \\
\text { H/A Z-score } \\
\geq-2)\end{array}$ & & & & \\
\hline & $\begin{array}{l}(n=35)(f, \\
\%)\end{array}$ & $\begin{array}{l}(n=216)(f, \\
\%)\end{array}$ & & & & \\
\hline $160-164.9$ & $23(23.0)$ & $36(26.7)$ & $1.06(0.53,2.13)$ & 0.859 & $1.17(0.57,2.39)$ & 0.662 \\
\hline more $=165$ & $7(7.0)$ & 15(11.1) & $0.78(0.28,2.12)$ & 0.624 & $0.87(0.31,2.45)$ & 0.787 \\
\hline
\end{tabular}

\section{Discussion}

We sought to establish the catch up growth, nutritional status and associated factors for children born with preterm/LBW at Mulago Hospital, Kampala. From our study, 101 (40.1\%) of the participants had caught up on normal growth for their age while the rest of the children had undernutrition. The prevalence of stunting was $42.2 \%$ and underweight $14.4 \%$ which are markers of chronic malnutrition; but relatively low levels of wasting 3.2\%, a marker of acute malnutrition. Stunting was associated with male sex, maternal age $\leq 25$ years and maternal height less than $150 \mathrm{~cm}$. Childhood underweight was associated with birth weight $\leq 1500$ grams and longer hospital stay of $>14$ days following delivery. The head circumference for $216(86.8 \% \%)$ was within normal range and MUAC for $246(98.8 \%)$ was $\geq 12.5 \mathrm{~cm}$ within normal range for age.

Less than half of our participants demonstrated catch up growth a prevalence lower than what was observed in other studies [13,14]. Mukhopadhyay et al in India showed no catch up growth beyond 2 years among extreme low birth weight infants [13]. A cross sectional study from 51 nations showed no catch-up growth from 2 to 5 years [17]. This showed a steep decline in children's height for age z-scores from birth to the first two years of life with no deterioration thereafter. The anthropometric parameters at two years can therefore fairly predict the growth outcomes later in life[17].

We enrolled children who were born preterm/LBW; these are a high risk for undernutrition[22] and this may explain the high prevalence of stunting demonstrated by our results. The prevalence of stunting in the children under- 5 years based on a Uganda national survey was $29 \%$ [23]. The same survey showed that stunting increased with age, peaking at 37 percent among children 18-35 months [24] in the general population.

In our study, stunting was associated with male sex, lower maternal age and lower maternal height. In our study, the boys $61 \%$ were more likely to be stunted compared to the girls $39 \%$. This is similar to other studies [25], although further studies are needed to evaluate the mechanism in which sex may contribute to stunting. Similar to previous studies $[26,27]$, our study demonstrated that young mothers had higher 
chances of having stunted children compared to older mothers. It is thought that older mothers are usually more knowledgeable in aspects of baby care compared to young and teenage mothers [26] hence the better outcome of their children. The maternal height could most probably be attributed to genetic and environmental factors. Studies have demonstrated mothers with short stature or those born with low birth weight were more likely to give birth to children with the same features $[17,25]$. Even though factors such as maternal education wealth quintile, maternal BMI have been described to be associated with stunting[24, 25, 28], our study did not find these to be associated with stunting.

Underweight was observed among $14.4 \%$ of our participants a prevalence slightly higher than the Uganda prevalence of $11 \%$ according to UDHS 2016, [23]. Underweight was associated with low birth weight and long hospital stay. In general, children who are born with low birth weight are at high risk of being underweight in their childhood which occasionally persists in adulthood [29]. It is possible that difficulties encountered in feeding low birth weight infants majority of whom are preterm babies, contributes to their poor growth in early childhood [30,31] .The finding that long hospital stay influences the ability of the baby to add weight and reach appropriate z-scores could be a marker of difficulties in feeding or generally ill-health which may hinder adequate feeding and growth. Only $3.2 \%$ of our study participants were wasted as compared to the $4 \%$ in the general population[24]. Wasting is an indicator of acute illness and we did not identify many children in whom recent acute illness was reported and this probably led to low prevalence.

Our findings have several implications on growth monitoring of children born preterm which should not be limited to the neonatal period but extend to childhood and beyond. Child growth and nutritional status may be strongly linked to fetal life suggesting a need for interventional focus on nutrition during pregnancy and early childhood. To end all forms of malnutrition by 2030: Sustainable Development Goal 2 [32], a life-course approach of nutritional interventions are needed targeting at risk populations. These will in turn lead to child survival, educational achievements and overall well- being later in life. Secondly, collection and analysis of long-term data in former preterm and LBW children linked to nutritional strategies and growth parameters are still strongly recommended in our setting. Although pre-pregnancy and natal nutritional status was not assessed in our study, they have been linked to growth failures in early childhood in other studies [33]. It is equally important to mind the mother's nutritional status from pre-conception throughout pregnancy $[17,34]$.

The strength of this study is we enrolled children who weighed less than 2000 grams at birth majority of whom will also be preterm. The predominant mode of feeding in our study population was exclusive breastfeeding with no modification for all the participants. The limitations included the cross sectional data does not reflect changes in growth of individual children overtime. Details of dietary intake and complimentary feeding practices were not collected in our study to minimize long term recall bias. Nevertheless, the results clearly indicate a need for rigorous growth monitoring for children born preterm/LBW beyond the neonatal period.

\section{Conclusion}


Of the children born preterm/LBW $40.1 \%$ of the participants had attained the expected catch up growth at 2 to 3 years of age, $42.2 \%$ were observed to be stunted and $14.4 \%$ were underweight both higher than the national levels. Targeted interventions are specifically needed for children born with very low birth weight, those requiring long postnatal hospitalization, males and those born to short or young mothers.

\section{Abbreviations}

AGA Appropriate for gestation age

CUG Catch up growth

LBW Low birth weight

\section{Declarations}

\section{Ethics approval and consent to participate}

The protocol was approved by Makerere University and Mulago Hospital Research and Ethics Committees (Ref 2019-117) and the Uganda National Council of Science \& Technology. The caretakers gave informed consent to participate in the study. All methods were performed in accordance with the relevant guidelines and regulations involving human research. Informed consent was verbally obtained from participant caregivers after needed information was explained. Participation was voluntary and caregivers signed or thumb printed a statement of an informed consent before being interviewed.

Consent for publication: All Authors approved manuscript for publication

Availability of data and materials: The data supporting the conclusions of this article are included within the manuscript.

Competing interests: The authors have no conflicts of interest to declare.

Funding: Support was from the Forgaty International Center of National Institutes of Health, U.S Department of State's Office of Global AIDS Coordinator and Health Diplomacy (S/GAC), and President's Emergency Plan for AIDS Relief (PEPFAR) under Award Number 1R25TW011213. The content is solely the responsibility of the authors and does not necessarily represent the official views of the National Institutes of Health.

Author Contributions: FN, JR, AB, NNB \& VK participated in concept development. SK \& IM reviewed the proposal. RS did the statistics and FN supervised the data collection and wrote initial manuscript. All authors contributed to revision of the final manuscript and approved it for submission.

Acknowledgements: We thank the Management of Mulago Hospital, Staff at the Preterm Clinic, Research Assistants: F Fawling, C. Akello \& F Nakirijja, the participants and their parents. My Mentors: Dr E Mupere, 
Dr A.Yasser, Dr D. Kyazze \& Mrs Maria Musisi.

\section{References}

1. Hannah Blencowe., Simon Cousens., Doris Chou., Mikkel Oestergaard., Lale Say., Ann-Beth Moller., Mary Kinney., Joy Lawn.: Born Too Soon: The global epidemiology of 15 million preterm births. Reproductive Health 2013, 10((Suppl 1): S2).

2. Howson C.P., Kinney V. M., Lawn E. J.: Born Too Soo: The Global Action Report on Preterm Birth. In: World Health Orgainization, Geneva Edited by March of Dimes P, Save the Children, WHO; 2012.

3. Lawn JE, Gravett MG, Nunes TM, Rubens CE, Stanton C, Group GR: Global report on preterm birth and stillbirth (1 of 7): definitions, description of the burden and opportunities to improve data. $B M C$ Pregnancy Childbirth 2010, 10 Suppl 1(Suppl 1):S1-S1.

4. Liu L, Johnson H., Cousens, S., Perin, J., Scott, S., et al, : Global, regional and national causes of child mortality in 2000-2013, with projections to inform post-2015 priorities: an updated systematic analysis. . The Lancet 2015, 385(9966):430-440.

5. Unicef, World Health Organization. A decade of tracking progress for maternal, newborn, and child survival: 2015 Report. Countdown to 2015. . In.: Unicef, World Health Organization.; 2015.

6. Pinto F, Fernades, E., Virella, D., Abrantes, A., Neto, T.M.,: Born Preterm: A Public Health Issue. Pertguese Journal of Public Health 2019, 10.

7. Vohr B.R.: Neonatal Follow up programs in the new Millenium. Neo-reviews 2001, 2(e):241-248.

8. Ho LY: Follow up care and Outcome Evaluation of High-Risk Preterm infants: A life-Course commitment. Editorial 2018.

9. Nutrition Landscape Information System (NLIS) country profile indicators: interpretation guide. In.: World Health Organisation; 2010.

10. WHO: World Health Organization Multicentre Growth Reference Study Group. WHO Child Growth Standards based on length/height, weight and age.I 2006. Acta Paediatr Supp/2006, 450(14):76-85.

11. Raaijmakers A, Allegaert K: Catch-Up Growth in Former Preterm Neonates: No Time to Waste. Nutrients 2016, 8(12):817.

12. A .M. Euser., C.C. de Wit., M.J.J. Finken., M. Rijken., Wit. JM: Growth of Preterm Born Children Hormone Research 2008, 70:319-328.

13. Kumar J, Mukhopadhyay K: Longitudinal Growth of Extremely Low Birth Weight Infants at 5 years. The Indian Journal of Pediatrics 2019, 86(12):1139-1141.

14. Bocca-Tjeertes IF., van Buuren S., Bos AF., Kerstjens JM., ten Vergert EM., SA. R: Growth in preterm and fullterm children aged 0-4 years: integrating median growth and variability into growth charts. Pediatrics 2012, 161:460-465.

15. Toftlund LH, Halken S, Agertoft L, Zachariassen G: Catch-Up Growth, Rapid Weight Growth, and Continuous Growth from Birth to 6 Years of Age in Very-Preterm-Born Children. Neonatology 2018, 114(4):285-293. 
16. Fink G, Sudfeld, C.R., Danael, G., Ezzati, M., Fawzi, W.W.,: "Scaling-Up Access to Family Planning May Improve Linear Growth and Child Development in Low and Middle Income Countries". PlosONE 2014, 9(7: e102391).

17. Leroy JL, Ruel M, Habicht J-P, Frongillo EA: Linear Growth Deficit Continues to Accumulate beyond the First 1000 Days in Low- and Middle-Income Countries: Global Evidence from 51 National Surveys. The Journal of Nutrition 2014, 144(9):1460-1466.

18. Lex W. Doyle., Peter J. Anderson., Malcom Battin., Jennifer R. Bowen., Brown. N: Long term follow up of high risk children: who,why and how? . BMC Pediatrics 2014, 14(279).

19. WHO: World Health Organization. Global targets 2025. To improve maternal, infant and young child nutrition. In.; 2014.

20. Ina S. Santos. AM, Marlos R. Domingues, Aluisio J.D. Barros., Cesar G. Victora., Fernando C. Barros. : Late preterm birth is a risk factor for growth falteringin early childhood: a cohort study. $B M C$ Pediatrics 2009, 9(17).

21. Victora CG dOM, Hallal PC, Blössner M, Shrimpton R.: Worldwide timing of growth faltering: revisiting implications for interventions. . Pediatrics 2010, 125:e473-480.

22. Luis Pereira-da-Silva., Daniel Virella., Fusch. C: Nutritional Assessment in Preterm Infants: A Practical Approach in the NICU. In: Nutrients. vol. 11; 2019.

23. Uganda Bureau of Statistics (UBOS) and ICF Internatioanl Inc, Uganda Demographic and Health Survey 2016. Kampala, Uganda: UBOS, and Rockville, Maryland, USA: UBOS and ICF. In.; 2018.

24. USAID. "Country Profile: Uganda: Nutrition Profile." In.; 2018.

25. Zhihui Li. RK, Sebastian Vollmer., S. V. Subramanian., : Factors Associated With Child Stunting, Wasting, and Underweight in 35 Low- and Middle-Income Countries. In., vol. 3. JAMA Network Open; 2020.

26. Wemakor A, Garti H, Azongo T, Garti H, Atosona A: Young maternal age is a risk factor for child undernutrition in Tamale Metropolis, Ghana. BMC research notes 2018, 11(1):877.

27. Yu SH, Mason J, Crum J, Cappa C, Hotchkiss DR: Differential effects of young maternal age on child growth. Global health action 2016, 9(1):31171.

28. Ozaltin E HK, Subramanian SV.: Association of maternal stature with offspring mortality, underweight, and stunting in low- to middle-income countries. . JAMA, 303:1507-1516.

29. Rahman MS, Howlader T, Masud MS, Rahman ML: Association of low-birth weight with malnutrition in children under five years in Bangladesh: do mother's education, socio-economic status, and birth interval matter? PloS one 2016, 11(6):e0157814.

30. Dusick AM, Poindexter BB, Ehrenkranz RA, Lemons JA: Growth failure in the preterm infant: can we catch up? In: Seminars in perinatology: 2003: Elsevier; 2003: 302-310.

31. Ziegler EE, Carlson SJ: Early nutrition of very low birth weight infants. The Journal of Maternal-Fetal \& Neonatal Medicine 2009, 22(3):191-197. 
32. Sachs J, Schmidt-Traub, G., Kroll, C., Durand-Declare, D., Teksoz, K.,: SDG Index and Dashboards report 2017. New York: Bertelsmann Stiftung and Sustainable Development Solutions Network (SDSN). In.; 2017.

33. Parul Christian SEL, Moira Donahue Angel, Linda S Adair, Shams E Arifeen et al: Risk of childhood undernutrition related to small-for-gestational age and preterm birth in low- and middle-income countries. International Journal of Epidemiology 2013, 42:1340-1355.

34. Black RE AL, Bhutta ZA, Caulfield LE, de Onis M, Ezzati M, Mathers C, Rivera J.: Maternal and child undernutrition: global and regional exposures and health consequences. . Lancet 2008, 371:243-260.

\section{Figures}

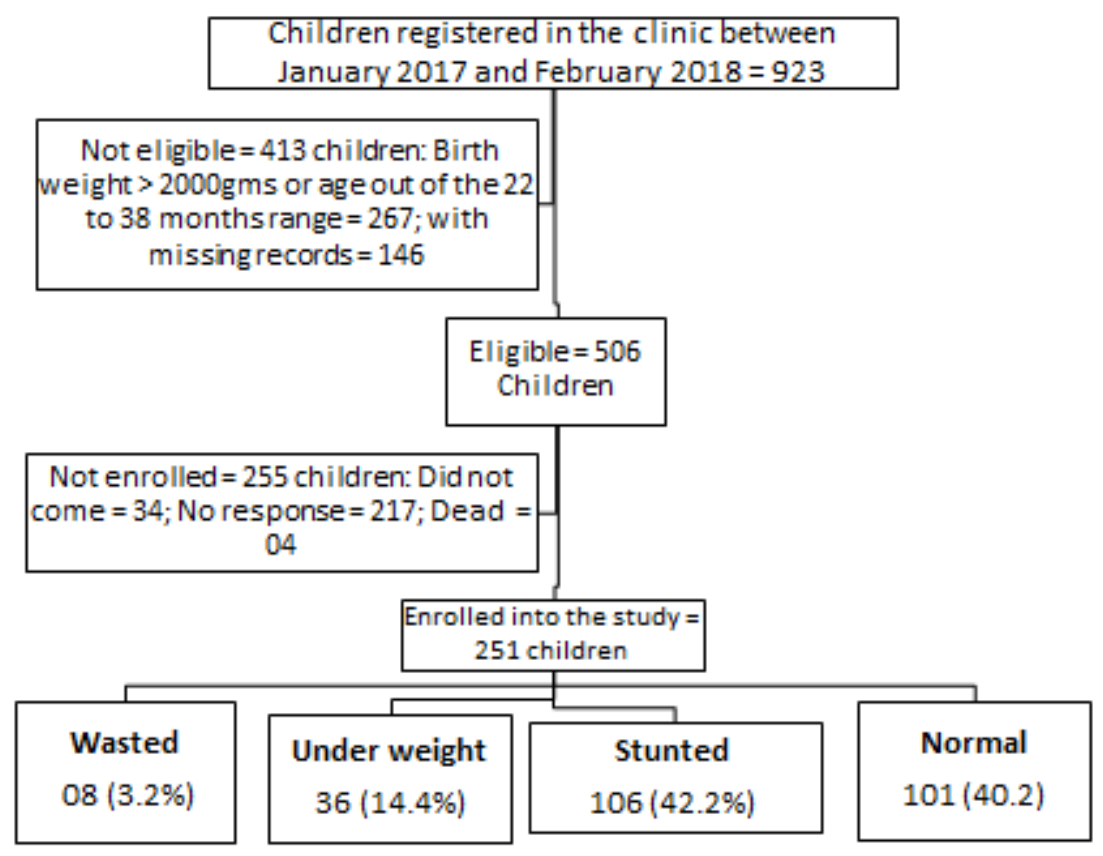

Figure 1

Participants Flow diagram 


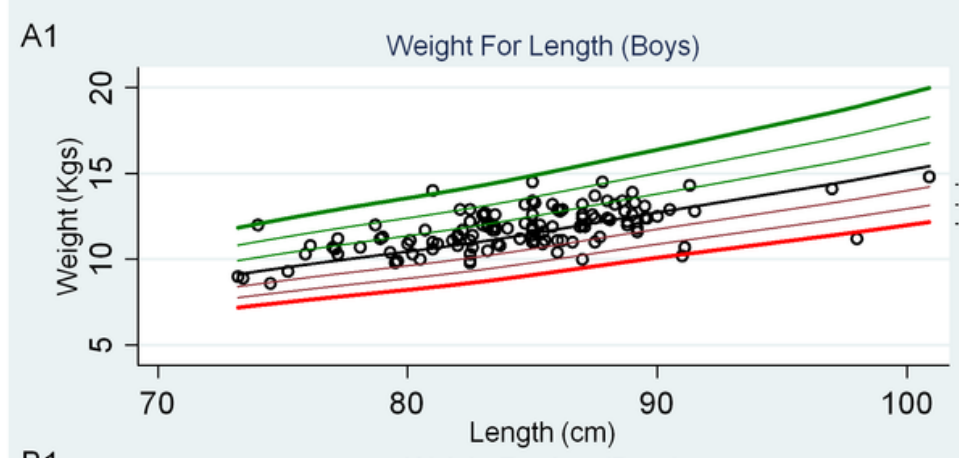

B1

Weight For Age (Boys)

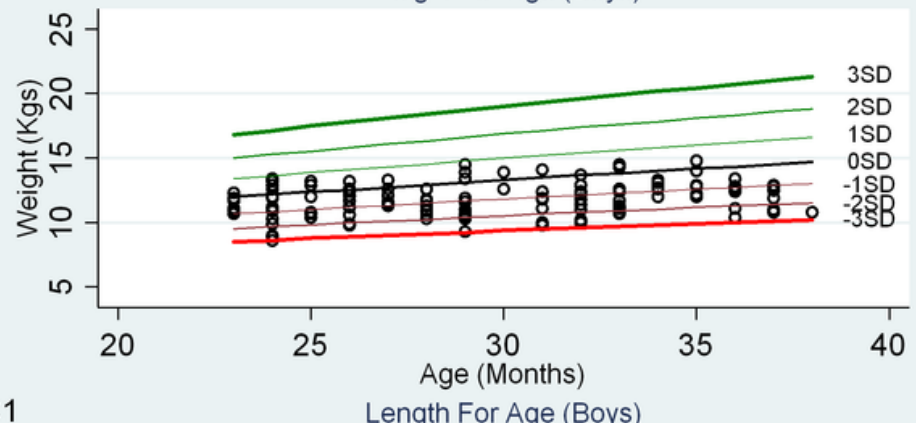

C1

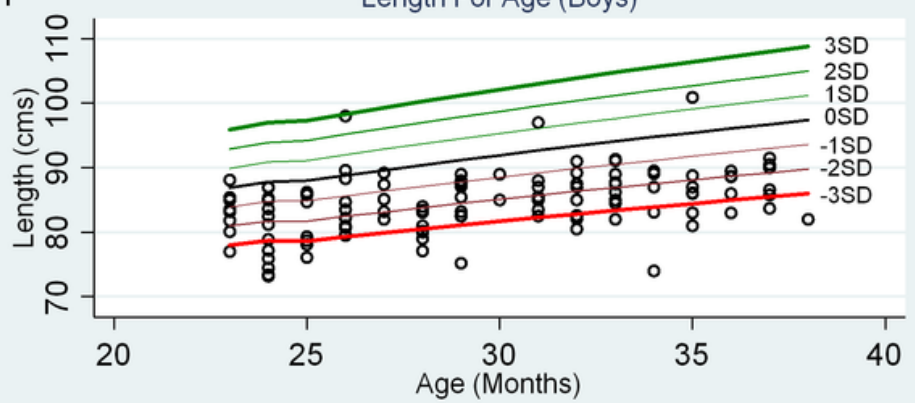

Reference: WHO Z-Scores

\section{Figure 1}

Scatter graphs showing the weights and heights of the participants by sex
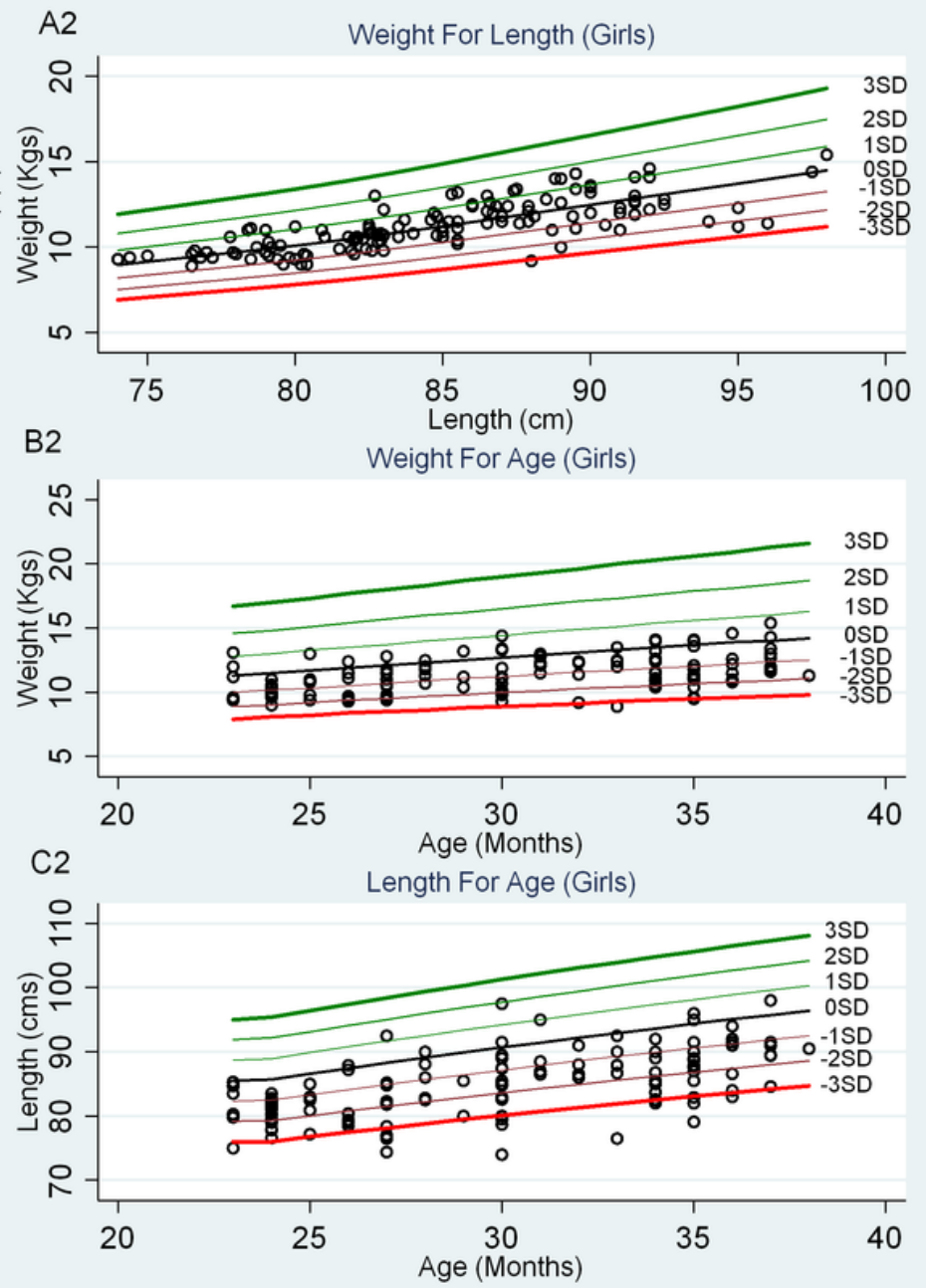